\title{
PENGGALIAN DAN PENYEBARAN POTENSI WISATA MELALUI APLIKASI MOBILE DENGAN KONSEP CROWDSOURCING
}

\author{
Oleh \\ I Ketut Resika Arthana ${ }^{1}$, Komang Setemen ${ }^{2}$, I Ketut Purnamawan ${ }^{3}$, Nyoman Dini \\ Andiani $^{4}$ \\ ${ }^{1}$ Jurusan Pendidikan Teknik Informatika, Fakultas Teknik dan Kejuruan \\ ${ }^{2,3}$ Jurusan Manajemen Informatika, Fakultas Teknik dan Kejuruan \\ ${ }^{4}$ Jurusan Manajemen Perhotelan, Fakultas Ekonomi dan Bisnis \\ UNIVERSITAS PENDIDIKAN GANESHA \\ email : resika@undiksha.ac.id, km_setemen@yahoo.com, \\ purnamawan@undiksha.ac.id, demeilovedini@gmail.com
}

\begin{abstract}
ABSTRAK
Pariwisata merupakan salah satu sektor yang sangat diminati oleh masyarakat. Keberadaan objek wisata memberikan dampak ekonomi bagi masyarakat sekitar dan pelaku pariwisata. Potensi-potensi pariwisata yang masih belum terpublikasi sudah seharusnya digali dan disebarkan sehingga masyarakat bisa memanfaatkan, baik sebagai pelaku pariwisata maupun penikmat pariwisata. Potensi wisata yang ada di Indonesia sangat tersebar dan tidak bisa dicari satu persatu. Penggalian potensi pariwisata memerlukan peran masyarakat untuk memberikan informasi keberadaan potensi wisata tersebut. Disisi lain, penggalian dan penyebaran potensi wisata seharusnya dibantu dengan teknologi informasi sehingga memberikan kemudahan bagi masyarakat untuk menginformasikan dan mencari objek wisata. Pada penelitian ini sudah dikembangkan aplikasi mobile untuk membantu masyarakat menginformasikan potensi wisata yang diketahuinya dengan menyertakan deskripsi, foto dan peta lokasi potensi objek wisata tersebut. Selain itu melalui aplikasi ini masyarakat juga dengan mudah mencari informasi objek wisata. Aplikasi yang dikembangkan memanfaatkan teknologi Android, GPS, Google Maps, serta mengadopsi konsep crowdsourcing. Secara keseluruhan penelitian ini menerapkan metodologi ADDIE (Analyze, Design, Development, Implementation dan Evaluation). Pengujian aplikasi dilakukan dengan Usability Testing. Pada pengujian menunjukkan rata-rata aspek learnability $85 \%$, memorability memiliki rata-rata $87 \%$, error memiliki rata-rata $95 \%$ dan satisfaction memiliki rata-rata sebanyak $95 \%$. Rata-rata keseluruhan pengujian adalah $90.5 \%$. Selain itu 90\% responden menyatakan bahwa aplikasi layak dipublikasikan.
\end{abstract}

Kata-kata kunci : Potensi Wisata, Google Maps, GPS, Crowdsourcing

\section{PENDAHULUAN}

Keberadaan pariwisata mampu meningkatkan perekonomian masyarakat seiring dengan berkembangnya industri yang berkaitan dengan objek pariwisata. Untuk itu objek wisata harus dikelola dengan baik dan informasinya disebarkan secara luas ke seluruh masyarakat. Meskipun saat ini Indonesia banyak memiliki objek wisata, namun masih banyak objek wisata yang belum tergali dan belum dikenal orang. Hal ini karena kurangnya informasi mengenai objek tersebut dan kurangnya fasilitas bagi masyarakat untuk mempublikasikan informasi potensi objek wisata tersebut.

Keberadaan pariwisata menimbulkan transaksi permintaan barang dan jasa sehingga memberikan peluang bagi masyarakat untuk meningkatkan kesejahteraannya. Selain dari sisi ekonomi pariwisata juga berdampak pada (1) dampak terhadap 
penerimaan devisa, (2) dampak terhadap pendapatan masyarakat, (3) dampak terhadap kesempatan kerja, (4) dampak terhadap harga-harga, (5) dampak terhadap distribusi masyarakat atau keuntungan, (6) dampak terhadap kepemilikan dan control, (7) dampak terhadap pembangunan pada umumnya dan (8) dampak terhadap pendapatan pemerintah.

Indonesia memiliki banyak objek wisata, sehingga Indonesia menjadi salah satu tujuan wisata dari mancanegara. Provinsi Bali merupakan salah tujuan wisata yang menjadi favorit dunia. Meskipun sudah terkenal banyak memiliki objek wisata, namun ternyata masih banyak objek yang berpotensi sebagai objek wisata yang belum tergali. Hal ini karena minimnya media yang mereka bisa gunakan untuk menginformasikan objek wisata yang mereka ketahui.

Penggalian potensi objek wisata harus melibatkan masyarakat luas untuk memberikan informasi keberadaan objek wisata tersebut. Untuk itu konsep yang tepat diadopsi adalah konsep Crowdsourcing. Konsep Crowdsourcing yang dimaksud adalah melibatkan masyarakat luas secara tidak terbatas tanpa memandang latar belakang pendidikan, agama, tingkat pengetahuan (Andriansyah, Oswari, \& Prijanto, 2011). Masyarakat tersebut secara sukarela memberikan kontribusinya atas suatu permasalahan yang dilemparkan.

Disisi lain, masyarakat yang ingin berwisata memerlukan teknologi untuk memudahkan menemukan objek wisata yang diinginkan. Untuk menentukan keputusan apakah akan berwisata pada objek tersebut, maka masyarakat pun perlu mengetahui tanggapan dan penilaian orang terhadap objek tersebut. Selain itu, informasi objek wisata yang terdekat dengan posisi saat ini dan rute untuk menuju lokasi tersebut juga perlu juga diketahui agar lebih mudah menuju lokasi objek wisata tersebut.

Pada penelitian ini akan dikembangkan teknologi tepat guna berupa perangkat lunak aplikasi mobile yag disebut dengan POTWIS. Aplikasi mobile POTWIS bermanfaat untuk menginformasikan potensi atau objek wisata yang diketahui dan menampilkan informasi objek wisata. Aplikasi POTWIS memanfaatkan teknologi LBS untuk memberikan informasi dalam bentuk peta, objek wisata terdekat dan rute menuju objek wisata tersebut. Aplikasi POTWIS dirancang dengan mengadopsi konsep Crowdsourcing dimana konten, tanggapan dan penilaian diberikan oleh masyarakat.

Pada tahap awal, dilakukan analisa kebutuhan sistem dan perancangan aplikasi penggalian potensi wisata ini dengan menggunakan pemodelan UML (I Ketut Resika Arthana, 2014). Selanjtunya dilakukan implementasi ke teknologi mobile (I Ketut Resika Arthana K. S., 2015) dan dilakukan pengujian dengan mengadopsi konsep Usability Testing.

\section{STUDI LITERATUR}

Pariwisata memegang peranan penting dalam pembangunan ekonomi dalam rangka meningkatkan kualitas hidup dan kesejahteraan masyarakat. Devisa yang dihasilkan dari pariwisata juga mampu meningkatkan perekonomian negara terutama sebagai pemasukan pemerintah untuk pembiayaan pelaksanaan tugas dan fungsi pemerintah. Beberapa indikator keberhasilan pariwisata diantaranya adalah tersedianya objek dan daya tarik wisata serta adanya ketertarikan wisatawan untuk memanfaatkan dan berkunjung ke tempat wisata tersebut. Untuk memunculkan ketersediaan objek wisata perlu dilakukan 
penggalian objek yang berpotensi sebagai objek wisata (Yoeti \& Oka, 1996). Selain itu untuk meningkatkan daya tarik wisata perlu peran serta masyarkat untuk memberikan informasi mengenai objek wisata dan diperlukan suatu cara menyebarkan informasi objek wisata secara luas ke calon wisatawan sehingga meningkatkan kunjungan ke objek wisata. Salah satu cara untuk mengakomodasi peran serta masyarakat dalam memberikan informasi objek wisata dan menyebarkan informasi objek wisata ke masyarakat luas adalah dengan memanfaatkan teknologi informasi. Beberapa penelitian yang memanfatkan teknologi informasi yang berkaitan dengan penggalian potensi objek wisata dan penyebaran informasi pariwisata diantaranya memanfaatkan teknologi Sistem Informasi Geografis (SIG), telepon seluler, teknologi web 2.0 terutama trend user generated content dan jejaring sosial.

Penelitian lain tentang SIG adalah dikembangkannya sistem informasi geografis potensi wisata alam kabupaten Tulungagung (Misbakhul Munir Zain, 2010). Tujuan dari penelitian ini adalah mempublikasikan potensi wisata alam yang terdapat pada kabupaten Tulungagung dengan memanfaatkan teknologi SIG. Perangkat lunak yang digunakan adalah ArcView GIS 3.3. Pada penelitian ini juga dianalisa tingkat daya tarik dan potensial wisata alam dengan metode skoring sehingga bisa menjadi acuan bagi pemerintah kabupaten dalam meningkatkan sarana dan prasarana untuk pengembangan objek wisata tersebut. Pada penelitian ini informasi potensi wisata ditentukan langsung oleh pengelola sistem. Hal ini membatasi munculnya objek wisata lain yang potensial yang tidak diketahui oleh pengelola sistem. Selain itu pada penelitian ini belum dibahas teknik penyebaran informasi objek wisata ke masyarakat luas.

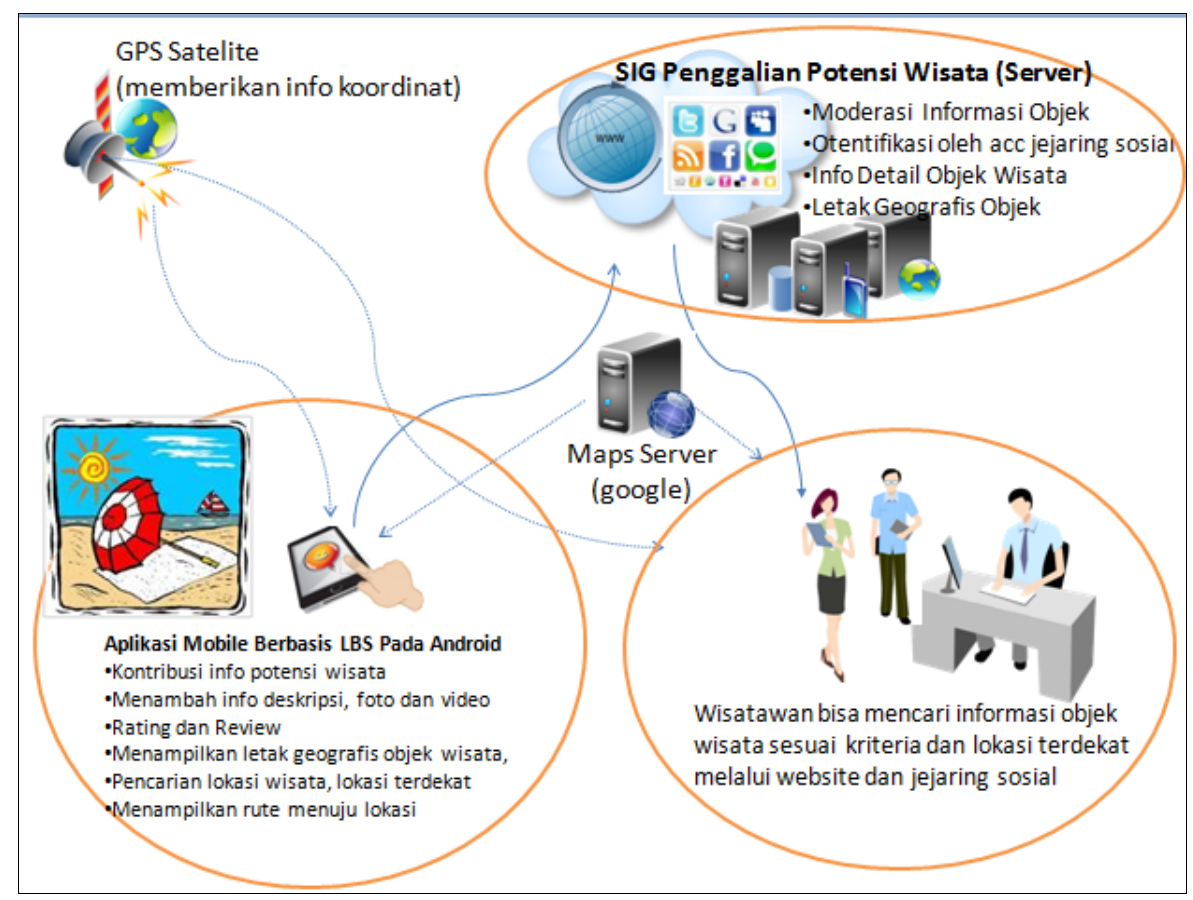

Gambar 1 Gambaran Sistem Informasi Penggalian Potensi Wisata

Selain itu penelitian yang berkaitan dengan informasi tempat wisata dengan memanfaatkan teknologi informasi adalah Aplikasi Wisata Kota Bandung Menggunakan

Penggalian dan Penyebaran Potensi Wisata. .(I Ketut Resika Arthana, Komang Setemen, I Ketut Purnamawan) 
Metode Location-Based Services (LBS) pada Android (Akbar Nuzul Putra, 2012). Pada penelitian ini dibangun suatu aplikasi yang disebut dengan TourisMo yang membantu wisatawan dibandung menemukan lokasi tempat wisata dengan teknologi Location Based Service berdasarkan titik koordinat dari GPS. Dengan aplikasi ini wisatawan bisa dengan mudah mengetahui lokasi objek wisata dan diberikan informasi route dari posisi berada saat ini sampai lokasi objek saat ini. Sedangkan pada penelitian lain (Pratiwi, 2012) fokus membangun sistem informasi wisata Jogjakarta pada aplikasi Android yang dilengkapi dengan peta lokasi.

\section{METODE PENELITIAN}

Pada penelitian ini mengadopsi model ADDIE. Model ADDIE terdiri dari lima tahapan yaitu Analyze, Design, Development, Implementation dan Evaluation.

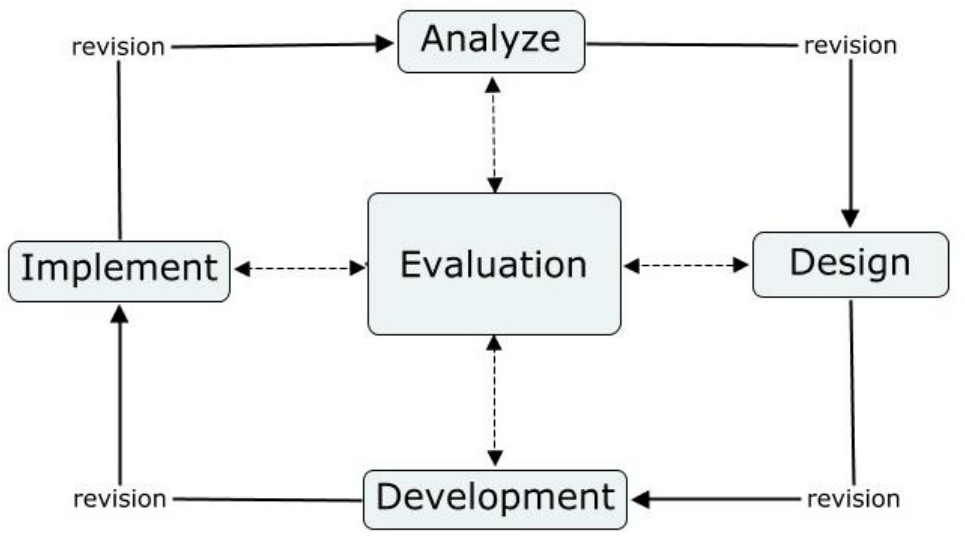

Gambar 2. Metodologi Pengembangan

\section{HASIL DAN PEMBAHASAN}

\subsection{ANALISIS}

\subsubsection{Teknik Pengumpulan Kebutuhan Sistem}

A. Kuisioner

Penggunaan kuisioner dipilih karena jumlah pemakai sistem yang akan dibangun tidak terbatas. Pengguna sistem adalah seluruh orang yang ingin mengetahui informasi tempat objek wisata dan orang yang ingin menginformasikan potensi objek wisata yang diketahuinya. Untuk memperoleh responden yang luas, maka kuisioner dibuat secara offline dan online. Kuisioner offline adalah kuisioner yang dicetak dan diisi secara manual oleh responden, sedangkan kuisioner online adalah kuisioner yang diletakkan di website sehingga orang yang ingin memberikan respon hanya perlu mengakses website kuisioner dan langsung menjawabnya. Alamat kuisioner online adalah di http://tinyurl.com/kuisionerPotensiWisata. Jumlah responden kuisioner ini 55 Responden dan Kuisioner disebarkan secara acak.

A.1. Kabupaten Asal Responden

JPTK, UNDIKSHA, Vol. 13, No. 1, Januari 2016 : 111 - 126 
Responden kuisioner penelitian ini berasal dari seluruh kabupaten yang ada di Bali. Sebagian besar responen berasal dari kabupaten Buleleng.

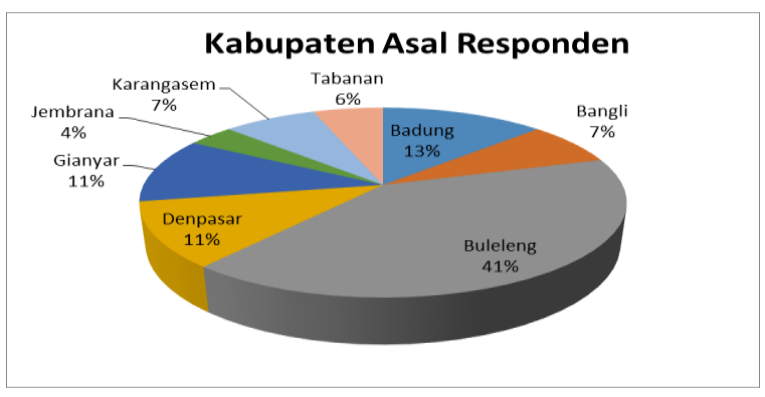

Gambar 3. Grafik Kabupaten Asal Responden

\section{A.2. Intensitas Berwisata}

Sebagian besar responden (72\%) berwisata sekitar 1 kali dalam sebulan, $11 \%$ dari responden menyatakan sekitar sekali dalam seminggu, 9\% menyatakan sangat jarang berwisata dan sisanya menyatakan lebih dari sekali dalam seminggu. Hal ini menunjukkan bahwa responden memiliki kebiasaan untuk berwisata. Dengan memiliki kebiasaan berwisata maka sistem yang akan dikembangkan memiliki layak untuk dikembangkan.

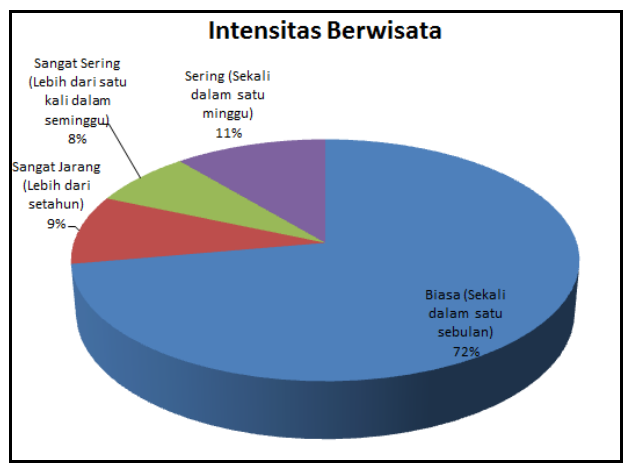

Gambar 4. Grafik Intensitas Berwisata

\section{A.3. Kesiapan Teknologi}

Sesuai dengan perkembangan teknologi, sebagian besar masyarakat sudah memiliki telepon seluler yang bisa mengakses internet. Begitu juga dengan perangkat GPS, sebagian besar telepon seluler mereka bisa dimanfaatkan untuk menentukan lokasi geografis melalui GPS. Selain itu, fitur kamera pada perangkat mobile sudah umum dimiliki pada telepon seluler mereka. 


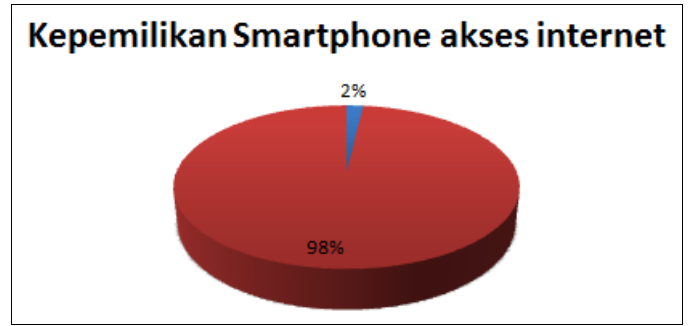

Gambar 5. Grafik kepemilikan telepon seluler untuk akses internet

\section{A.4. Kebutuhan Responden}

Dari hasil kuisioner diperoleh daftar kebutuhan aplikasi yang diinginkan oleh responden. kebutuhan aplikasi oleh pengguna meliputi terdapat petunjuk rute dalam bentuk peta menuju lokasi objek wisata, petunjuk rute yang bisa disimpan secara offline, fasilitas terdekat dengan objek tersebut (hotel, kuliner), tarif masuk ke objek wisata, integrasi dengan sosial media, informasi fasilitas pada objek wisata, informasi detail objek wisata (alamat, detail dan deskripsi), Augmented Reality objek wisata, fitur mengambil dan upload foto, fitur komentar terhadap foto dan konten, informasi Objek Wisata bisa dishare di sosial media, informasi Sejarah peresmian objek wisata, menampilkan temanteman yang ada objek wisata yang sama, chatting dengan orang yang ada pada objek wisata tersebut, keadaan Objek secara real, multibahasa, keakuratan lokasi objek wisata, fitur pencarian objek wisata (auto recomend), video objek wisata, galery objek wisata dan fitur teks to speech.

\section{B. Observasi Lapangan}

Dalam penelitian ini juga dilakukan observasi ke lapangan untuk mengidentifikasi karakteristik objek-objek wisata dan mengumpulkan data potensi objek wisata.

Dalam melakukan observasi ke lapangan peneliti mengalami beberapa permasalahan yaitu:

1) Belum adnya informasi petunjuk rute menuju objek wisata yang memadai, untuk itu diperlukan membangun fitur informasi rute menuju lokasi tersebut.

2) Informasi yang ada dilapangan tidak sesuai dengan informasi yang ditulis di media informasi (online atau cetak). Untuk itu di perlukan fitur untuk mengupdate kondisi saat ini di potensi objek wisata.

3) Informasi objek wisata yang kurang memadai mengakibatkan orang yang berwisata kesulitan mengetahui bagian-bagian objek wisata. Untuk itu diperlukan informasi lengkap dan detail mengenai objek tersebut.

4) Perlunya pendokumentasian objek wisata baik dalam bentuk teks, video dan audio untuk memperkaya informasi pada objek wisata.

C. Analisa Sistem Yang Sudah Ada

Terdapat beberapa sistem informasi wisata dan penelitian sebelumnya yang diamati untuk mendapatkan fitur yang sudah ada sebelumnya. Sebagian besar penelitian yang sudah ada sudah mengimplementasikan sistem informasi geografis dan LBS pada penelitian mereka seperti Aplikasi Wisata Kota Bandung Menggunakan Metode Location-Based Services 
(LBS) pada Android (Akbar Nuzul Putra, 2012), Pengembangan Potensi Wisata Alam Kabupaten Tulungagung dengan Sistem Informasi Geografis (Misbakhul Munir Zain, 2010) dan SISTEM INFORMASI GEOGRAFIS PARIWISATA KOTA SEMARANG (Ambrina Kundyanirum, 2013). Hal ini dikarenakan dengan sistem informasi geografis maka orang akan mudah mengetahui lokasi objek tersebut secara geografis. Teknologi sistem informasi geografis sebagian besar menggunakan Google Maps karena selain gratis, teknologi ini juga sangat user friendly baik dalam pengembangan maupun penggunaan. Namun sangat jarang aplikasi yang membahas sumber konten objek wisata pada penelitian yang sudah ada. Sebagian besar aplikasi dan sistem informasi yang sudah ada memiliki sumber informasi objek wisata dari pihak pemilik aplikasi tersebut seperti pada website Wisata Indonesia Surga Dunia(http://erawisata.com/), wisata indonesia, wisata alam dan wisata kuliner (http://wisataindonesia.net/). Kelemahan dari sistem informasi ini adalah terbatasnya pengetahuan pemilik aplikasi tersebut untuk memberikan informasi objek wisata dan potensi objek wisata. Untuk itu perlu ditambahkan fitur mengijinkan pengguna sistem informasi menyumbangkan informasi potensi objek wisata.

\subsubsection{Kebutuhan Fungsional}

Berdasarkan analisa dari sisi teknologi serta batasan dalam mengerjakan penelitian ini, maka kebutuhan fungsional yang didapatkan dari pengguna dikelompokkan dan disederhanakan sebagai berikut:

1. Melakukan proses pencarian objek wisata

2. Menampilkan peta dan rute menuju lokasi objek wisata

3. Manipulasi data objek wisata

4. Menampilkan informasi detail objek wisata

5. Menambahkan objek wisata baru

6. Menambahkan informasi pada objek wisata yang sudah ada

7. Memberi komentar pada objek wisata

8. Memberikan rating pada objek wisata

9. Membagi informasi objek wisata ke sosial media

10. Checkin pada lokasi objek wisata

11. Menggunakan account sosial media untuk login ke aplikasi

\subsubsection{Kebutuhan Non Fungsional}

1. Availability - Ketersediaan Aplikasi untuk dapat diakses oleh pengguna.

2. Reliability - Kehandalan Aplikasi, termasuk aspek teknis seperti koneksi, kebutuhan hardware. Hardware yang dibutuhkan harus handal dan bisa menangani request banyak serta menyimpan data yang besar. Pada aplikasi memerlukan koneksi internet (download) yang memadai dan pada sisi server memerlukan koneksi internet (upload) yang bisa melayani request aplikasi.

3. Ergonomy - Desain Aplikasi harus disesuaikan dengan kenyamanan pengguna. Aplikasi menggunakan pewarnaan dan tata letak yang nyaman digunakan oleh pengguna aplikasi.

4. Portability - Keberpindahan Aplikasi, sehingga dapat diakses oleh berbagai device.

Penggalian dan Penyebaran Potensi Wisata .(I Ketut Resika Arthana, Komang

Setemen, I Ketut Purnamawan) 
5. Aplikasi web dibuat Responsive yaitu bisa dibuka melalui browser mobile dan komputer. Layar Aplikasi mobile mendukung layar perangkat mobile secara umum.

6. Kebutuhan memory untuk menjalankan aplikasi mendukung rata-rata ketersediaan memory smartphone/handphone saat ini.

7. Response time - Waktu Aplikasi untuk merespon request dari user memenuhi standar kenyamanan pengguna.

8. Security - Keamanan aplikasi untuk melindungi data di dalamnya.

9. Password pengguna dalam kondisi terenkripsi tersimpan dalam database.

\subsection{Design}

\subsubsection{Diagram Use Case}

Daftar kebutuhan fungsional sistem selanjutnya digambarkan dalam bentuk diagram Use Case.

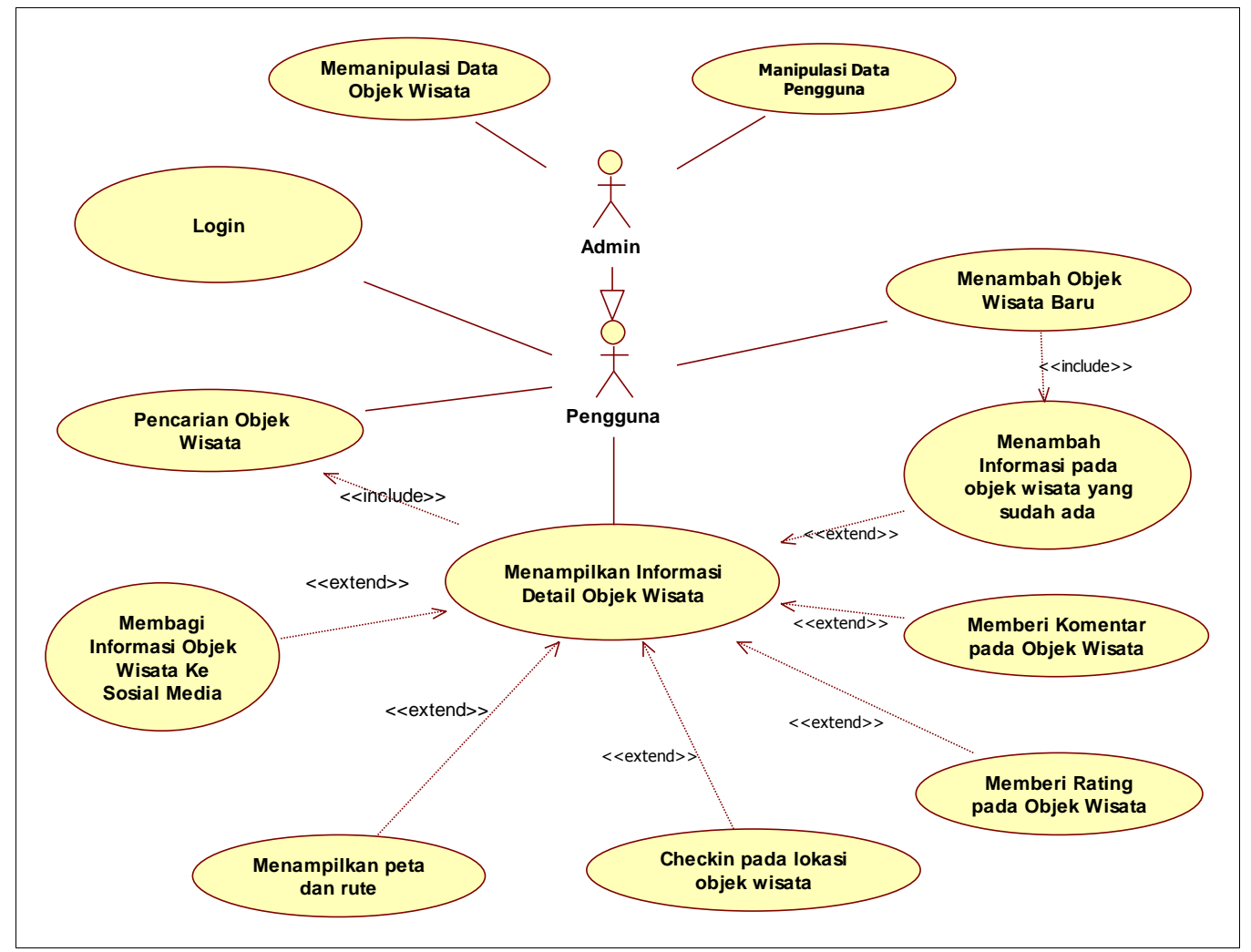

Gambar 6. Diagram Use Case 


\subsubsection{Arsitektur Sistem}

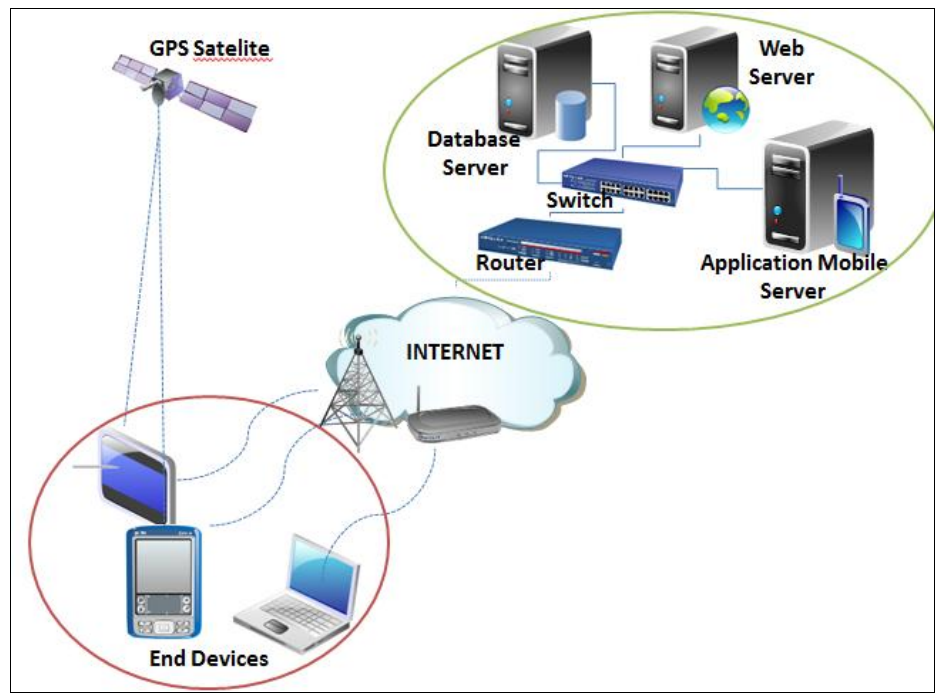

Gambar 7. Arsitektur Sistem

Aplikasi yang dikembangkan dalam penelitian ini berbasis client server. Pada sisi server terdiri dari database server, web server dan application mobile server. Server tersebut terletak pada internet dan bisa diakses melalui aplikasi mobile. Sedangkan koordinat GPS diberikan oleh satelit GPS yang mengorbit di luar angkasa.

\subsection{Development}

Pada tahapan ini, rancangan sistem yang telah dibuat sebelumnya dikembangkan menjadi perangkat lunak. Pengembangan aplikasi melibatkan perangkat lunak yang berfungsi untuk mengembangkan sistem, baik dari sisi server maupun client. Perangkat lunak yang dihasilkan pada tahapan ini meliputi aplikasi mobile berbasis Android yang disebut dengan aplikasi POTWIS dan website POTWIS.

Berdasarkan analisis kebutuhan sistem dan rancangan yang telah dibuat pada tahapan sebelumnya, telah didefinisikan daftar kebutuhan fungsional yang harus dipenuhi. Berikut pemetaan daftar kebutuhan sistem dengan tools yang dikembangkan serta ftur yang dihasilkan. 
Tabel 1. Pemetaan Kebutuhan Fungsional dengan Fitur pada aplikasi mobile

\begin{tabular}{|c|c|c|}
\hline $\begin{array}{l}\text { Kebutuhan } \\
\text { Fungsional }\end{array}$ & Tools & Fitur pada Aplikasi Mobile \\
\hline $\begin{array}{l}\text { Mendaftar ke } \\
\text { aplikasi }\end{array}$ & $\begin{array}{l}\text { Android Studio, Android SDK dan } \\
\text { ADT, MySQL, PHP, JSON, Restfull } \\
\text { WebService }\end{array}$ & Menu Daftar, Halaman Daftar \\
\hline Login ke aplikasi & $\begin{array}{l}\text { Android Studio, Android SDK dan } \\
\text { ADT, MySQL, PHP, JSON, Restfull } \\
\text { WebService, Google API, Facebook } \\
\text { API }\end{array}$ & Halaman login \\
\hline $\begin{array}{l}\text { Menampilkan } \\
\text { daftar Objek } \\
\text { Wisata }\end{array}$ & $\begin{array}{l}\text { Android Studio, Android SDK dan } \\
\text { ADT, MySQL, PHP, JSON, Restfull } \\
\text { WebService }\end{array}$ & Halaman daftar objek wisata \\
\hline $\begin{array}{l}\text { Menampilkan detil } \\
\text { Objek Wisata }\end{array}$ & $\begin{array}{l}\text { Android Studio, Android SDK dan } \\
\text { ADT, MySQL, PHP, JSON, Restfull } \\
\text { WebService }\end{array}$ & Halaman detil objek wisata \\
\hline $\begin{array}{l}\text { Menampilkan } \\
\text { komentar objek } \\
\text { wisata }\end{array}$ & $\begin{array}{l}\text { Android Studio, Android SDK dan } \\
\text { ADT, MySQL, PHP, JSON, Restfull } \\
\text { WebService }\end{array}$ & $\begin{array}{l}\text { Halaman komentar dan rating objek } \\
\text { wisata }\end{array}$ \\
\hline $\begin{array}{l}\text { Menampilkan } \\
\text { rating objek wisata }\end{array}$ & $\begin{array}{l}\text { Android Studio, Android SDK dan } \\
\text { ADT, MySQL, PHP, JSON, Restfull } \\
\text { WebService }\end{array}$ & $\begin{array}{l}\text { Halaman komentar dan rating objek } \\
\text { wisata }\end{array}$ \\
\hline $\begin{array}{l}\text { Menambah } \\
\text { komentar dan } \\
\text { Menambah Rating } \\
\end{array}$ & $\begin{array}{l}\text { Android Studio, Android SDK dan } \\
\text { ADT, MySQL, PHP, JSON, Restfull } \\
\text { WebService }\end{array}$ & $\begin{array}{l}\text { Halaman tambah komentar dan } \\
\text { rating objek wisata }\end{array}$ \\
\hline $\begin{array}{l}\text { Checkin pada } \\
\text { lokasi }\end{array}$ & $\begin{array}{l}\text { Android Studio, Android SDK dan } \\
\text { ADT, MySQL, PHP, JSON, Restfull } \\
\text { WebService, GPS, LBS }\end{array}$ & $\begin{array}{l}\text { Halaman tambah komentar dan } \\
\text { rating objek wisata }\end{array}$ \\
\hline $\begin{array}{l}\text { Membagi ke sosial } \\
\text { media }\end{array}$ & $\begin{array}{l}\text { Android Studio, Android SDK dan } \\
\text { ADT, MySQL, PHP, JSON, Restfull } \\
\text { WebService, GPS, LBS, Facebook } \\
\text { API }\end{array}$ & Tombol share facebook \\
\hline $\begin{array}{l}\text { Menambah } \\
\text { deskripsi pada } \\
\text { objek wisata yang } \\
\text { sudah ada }\end{array}$ & $\begin{array}{l}\text { Android Studio, Android SDK dan } \\
\text { ADT, MySQL, PHP, JSON, Restfull } \\
\text { WebService }\end{array}$ & $\begin{array}{l}\text { Halaman tambah deskripsi objek } \\
\text { wisata }\end{array}$ \\
\hline $\begin{array}{l}\text { Pencarian } \\
\text { berdasarkan nama } \\
\text { dan alamat objek } \\
\text { wisata }\end{array}$ & $\begin{array}{l}\text { Android Studio, Android SDK dan } \\
\text { ADT, MySQL, PHP, JSON, Restfull } \\
\text { WebService }\end{array}$ & $\begin{array}{l}\text { Form pencarian pada halaman daftar } \\
\text { objek wisata }\end{array}$ \\
\hline $\begin{array}{l}\text { Pencarian } \\
\text { berdasarkan } \\
\text { alamat terdekat }\end{array}$ & $\begin{array}{l}\text { Android Studio, Android SDK dan } \\
\text { ADT, MySQL, PHP, JSON, Restfull } \\
\text { WebService }\end{array}$ & $\begin{array}{l}\text { Tombol urutkan jarak terdekat pada } \\
\text { halaman daftar objek wisata }\end{array}$ \\
\hline $\begin{array}{l}\text { Menampilkan peta } \\
\text { lokasi objek wisata }\end{array}$ & $\begin{array}{l}\text { Android Studio, Android SDK dan } \\
\text { ADT, MySQL, PHP, JSON, Restfull } \\
\text { WebService, Google Maps API }\end{array}$ & $\begin{array}{l}\text { Peta lokasi pada halaman detail objek } \\
\text { wisata dan peta keseluruhan pada } \\
\text { menu utama }\end{array}$ \\
\hline $\begin{array}{l}\text { Menampilkan rute } \\
\text { menuju objek } \\
\text { wisata }\end{array}$ & $\begin{array}{l}\text { Android Studio, Android SDK dan } \\
\text { ADT, MySQL, PHP, JSON, Restfull } \\
\text { WebService, GPS, LBS, Google } \\
\text { Navigations }\end{array}$ & Google Maps (Aplikasi External) \\
\hline $\begin{array}{l}\text { Menambah objek } \\
\text { wisata }\end{array}$ & $\begin{array}{l}\text { Android Studio, Android SDK dan } \\
\text { ADT, JSON, Restfull WebService }\end{array}$ & Halaman nama objek wisata \\
\hline $\begin{array}{l}\text { Manipulasi objek } \\
\text { wisata }\end{array}$ & PHP, MysQL & $\begin{array}{l}\text { Halaman web, manipulasi objek } \\
\text { wisata }\end{array}$ \\
\hline $\begin{array}{l}\text { Manipulasi } \\
\text { informasi konten } \\
\text { objek wisata }\end{array}$ & PHP, MysQL & $\begin{array}{l}\text { Halaman web manipulasi konten } \\
\text { objek wisata }\end{array}$ \\
\hline
\end{tabular}


A. Login dengan jejaring sosial.

Aplikasi POTWIS dilengkapi dengan fitur login dengan jejaring sosial. Fitur ini berfungsi untuk memudahkan pengguna dalam memanfaatkan aplikasi. Pengguna tidak perlu membuat username dan password lagi untuk aplikasi ini. Pengguna cukup menggunakan account jejaring sosialnya seperti Facebook dan Google Plus.

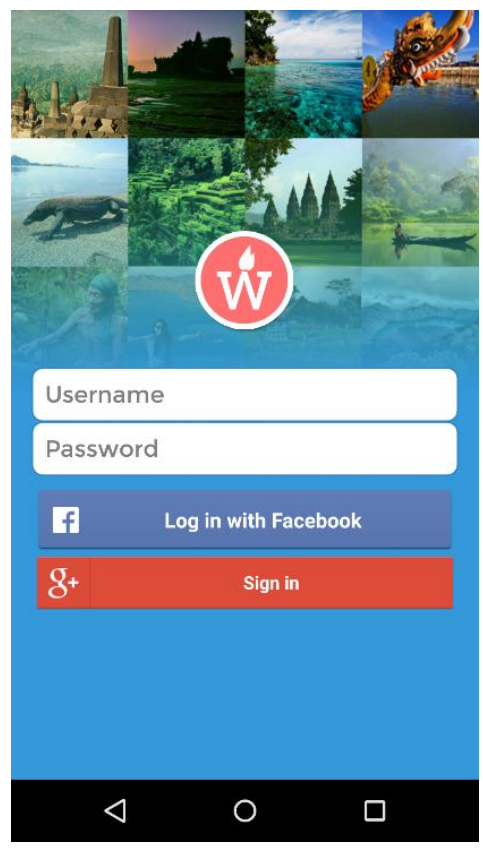

Gambar 8. Halaman Login

B. Halaman yang menampilkan daftar objek wisata

Informasi yang ditampilkan pada halaman ini adalah daftar objek wisata yang sudah didaftarkan. Pada halaman ini dilengkapi juga dengan pencarian berdasarkan kata kunci maupun berdasarkan jarak terdekat. 


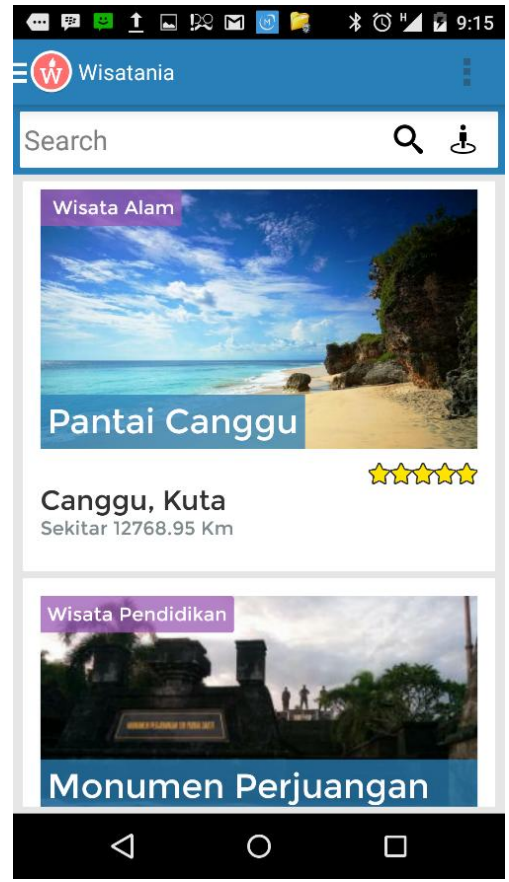

Gambar 9. Daftar Objek Wisata

C. Halaman detail objek wisata

Pada halaman ini terdapat informasi detail objek wisata. Informasi yang ditampikan pada halaman ini meliputi nama objek wisata, peta lokasi, foto utama, jenis, tombol untuk melihat rute menuju lokasi objek wisata tersebut, tombol untuk melihat komentar dan penilaian, tombol untuk melihat gambar-gambar terkait objek wisata tersebut, tombol untuk menambah informasi objek wisata, dan tombol untuk melaporkan jika objek wisata tidak sesuai. 


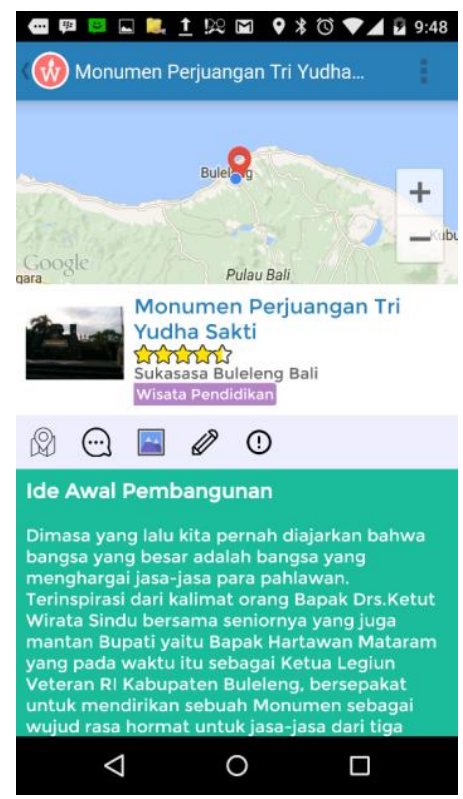

Gambar 10. Informasi Detail Objek Wisata

D. Informasi rute menuju lokasi objek wisata

Informasi menuju lokasi objek wisata memanfaatkan perangkat GPS yang ada pada perangkat mobile dan memanfaatkan Google Maps Api. GPS berfungsi untuk memberikan informasi koordinat saat ini sebagai titik acuan menuju lokasi objek wisata. Setelah koordinat titik sumber dan tujuan tersedia, aplikasi POTWIS akan melakukan request ke Google API untuk menampilkan rute menuju lokasi objek wisata tersebut.

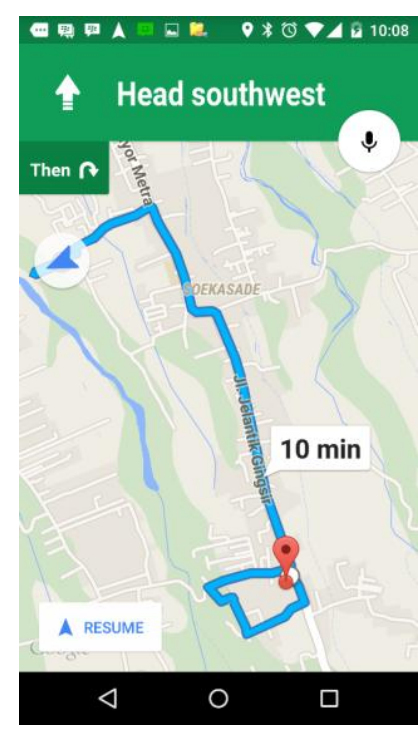

Gambar 11. Rute menuju lokasi objek wisata 
E. Halaman komentar dan rating objek wisata

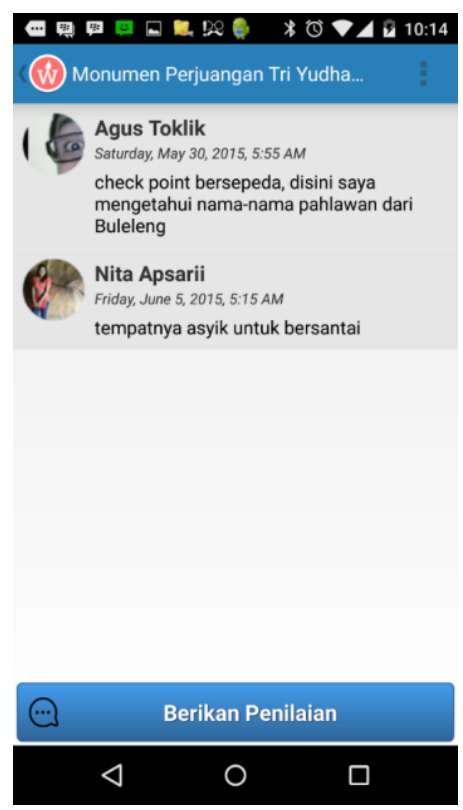

Gambar 12. Komentar pada Objek Wisata

F. Menambah informasi atau konten baru terkait objek wisata tersebut

Pada halaman detail infomasi objek wisata ditampikan deskripsi objek wisata. Deskripsi ini ditambahkan oleh pengguna. Pengguna lain juga bisa menambahkan deskripsi yang berkaitan dengan objek wisata tersebut.

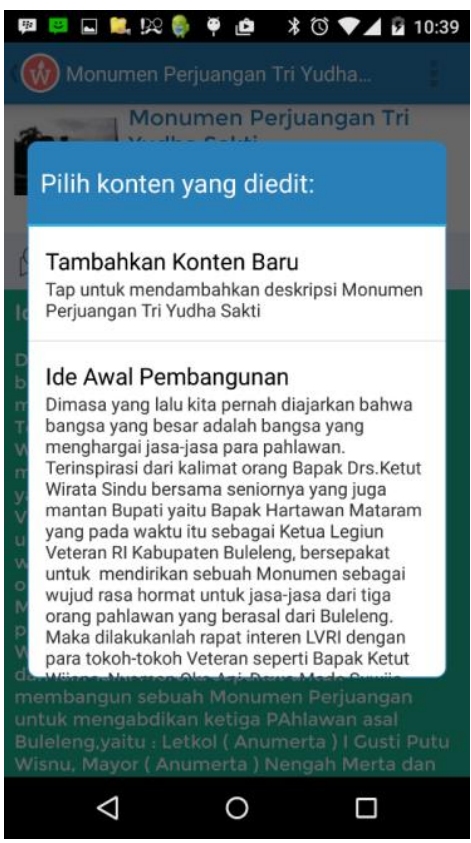

Gambar 13. Menambah atau Mengedit Konten Objek Wisata 


\subsection{Implementation}

Sistem yang telah dikembangkan kemudian diimplementasikan pada perangkat Android dan website yang telah dikembangkan diinstall ke server. Spesifikasi perangkat android yang digunakan untuk uji coba adalah sebagai berikut

$\begin{array}{ll}\text { Network } & \text { Technology GSM / CDMA / HSPA / LTE } \\ \text { WLAN } & \text { Wi-Fi 802.11 a/b/g/n/ac } \\ \text { Bluetooth } & \text { v4.0, A2DP } \\ \text { GPS } & \text { Yes, with A-GPS, GLONASS } \\ \text { Internal } & \text { 16/32 GB, } \text { GB RAM } \\ \text { Camera } & \text { 8 MP } \\ \text { GPS } & \text { Yes, with A-GPS, GLONASS }\end{array}$

\subsection{Evaluation}

Pengujian aplikasi ini dilakukan dengan menyebarkan kuisioner ke pengguna aplikasi. Isi kuisioner mengadopsi dari standar pengujian Usability versi JACOB NIELSON. Adapun aspek-aspek yang diujikan meliputi Learnability (kemudahan aplikasi untuk dipelajari), Efficiency (Langkah-langkah untuk menyelesaikan masalah secara efisien), Memorability (proses mudah diingat), Error (tidak terjadi kesalahan dalam menggunakan aplikasi) dan User Satisfaction (kepuasan pengguna). Tahap pertama pengujian menunjukkan rata-rata aspek Learnability adalah 72\%, Memorability 70\%, Error 64\% dan Satisfaction $80 \%$. Rata-rata pengujian tahap pertama adalah $71.5 \%$. Selain itu $85 \%$ responden menyatakan bahwa aplikasi layak dipublikasikan dengan beberapa perbaikan. Setelah itu dilakukan perbaikan pada aplikasi sesuai dengan masukan responden. Pada pengujian tahap kedua rata-rata aspek learnability $85 \%$, memorability memiliki rata-rata $87 \%$, error memiliki rata-rata $95 \%$ dan satisfaction memiliki rata-rat sebanyak $95 \%$. Rata-rata hasil pengujian tahap kedua adalah $90.5 \%$. Selain itu 90\% responden menyatakan bahwa aplikasi layak dipublikasikan.

\section{PENUTUP}

Kesimpulan yang diperoleh dalam penilitian ini meliputi :

1. Pada penelitian ini sudah dikembangkan aplikasi penggalian potensi wisata yang disebut dengan POTWIS. Aplikasi ini berfungsi untuk menggali dan menyebarkan potensi wisata dengan memanfaatkan teknologi Mobile.

2. Tahapan pengembangan aplikasi terdiri dari Analisis, Desain, Development (Pengembangan), Implementasi dan Evaluasi.

3. Aplikasi POTWIS dikembangkan dengan menggunakan perangkat lunak Android Studio, Android SDK dan ADT, Facebook dan Google API, web service, JSON, PHP dan MySQL.

4. Hasil pengujian menunjukkan bahwa aplikasi POTWIS sudah layak untuk dipublikasikan. Saat ini aplikasi POTWIS sudah dipublikasikan di Google PlayStore.

Penggalian dan Penyebaran Potensi Wisata .(I Ketut Resika Arthana, Komang

Setemen, I Ketut Purnamawan) 


\section{DAFTAR PUSTAKA}

\section{APLIKASI INFORMASI OBJEK WISATA DAN PETA LOKASI DI JOGJA PADA MOBILE ANDROID2012E-Journal Teknologi Industri-Universitas Gunadharma}

Aplikasi Wisata Kota Bandung Menggunakan Metode Location-Based Services (LBS) pada Android

Crowdsourcing: Konsep Sumber Daya Kerumunan dalam Abad Partisipasi Komunitas Internet 2011

Pengembangan Potensi Wisata Alam Kabupaten Tulungagung dengan Sistem Informasi GeografisUndergraduate Theses ITS Library

Rancangan Sistem Informasi Geografis Penggalian Dan Penyebaran Potensi Wisata Berdasarkan Kontribusi Masyarakat Berbasis Mobile2014Seminar Nasional Riset Inovatif Kuta-BaliLemlit Undiksha

The ADDIE Model: Instructional Design2014

WISATANIA : Aplikasi Mobile Untuk Menggali dan Menyebarkan Potensi Wisata Berdasarkan Kontribusi Masyarakat2015Seminar Nasional Teknik Informatika dan KomputerDepokPoliteknik Negeri Jakarta

YoetiOka1996Pemasaran PariwisataBandungAngkasa 